\title{
ECONOMIC DIPLOMACY IS A PRIORITY OF UZBEKISTAN'S FOREIGN POLICY AT THE PRESENT STAGE
}

\author{
Iskandar Urokboev \\ Master, World Economy And Diplomacy University, Uzbekistan \\ Shahboz Doniyorov \\ Master Tashkent State University Of Economics, Uzbekistan
}

\section{ABSTRACT}

Active implementation of economic diplomacy in the foreign policy of Uzbekistan is one of the priorities of today. Because, in the active promotion of economic diplomacy, it is important to attract investment, increase tourism and export potential. The growing role of economic diplomacy in the system of international relations shows that it should be applied in the foreign policy of Uzbekistan. The article discusses the current work in this direction and its prospects.

KEYWORDS: - Economic diplomacy, foreign policy, investment, tourism.

\section{INTRODUCTION}

At the current time, the process of globalization is growing rapidly. This increases the role of economic diplomacy in the system of international relations. These important changes on a global scale, in turn, require a balanced, mutually beneficial and constructive approach to foreign policy. Therefore, economic diplomacy, which is one of the priorities of foreign policy of our country, is receiving significant attention in recent years.

We must first know what the goals of economic diplomacy are. Economic diplomacy is the activity of state institutions with the involvement of public and business structures, the application of knowledge of modern economic, political, legal sciences and tools, methods and forms of modern diplomacy, the use of bilateral and multilateral institutions in order to implement national economic interests in the world arena aimed at sustainable and stable development of the socially oriented market economy of the country.[1] Therefore, based on the above tariffs, we can say that the active use of economic diplomacy in foreign policy contributes to the economic development of the country and accelerates the flow of investment. This is an important contribution to the well-being of the people.

By the Decree of the President of the Republic of Uzbekistan Shavkat Mirziyoyev dated February 7, 2017, paragraph 264 of the State Program "Year of Youth Support and Public Health" of the 
CURRENT RESEARCH JOURNAL OF HISTORY 2(9): 32-35, September2021

DOI: https://doi.org/10.37547/history-crjh-02-09-09

ISSN 2767-472X

(C)2021 Master Journals

\section{Crossref dof 81 Google}

Accepted 25 ${ }^{\text {th }}$ September, 2021 \& Published 30th September, 2021

Action Strategy for 2021 provides for "active promotion of economic diplomacy in the foreign policy of the Republic of Uzbekistan". In particular, the Ministry of Foreign Affairs has developed an action plan in this regard. According to the plan:

- Assistance to entrepreneurs in establishing contacts with new foreign partners in order to further increase the export potential of the country;

- practical assistance in attracting foreign investment to regional projects;

- Attracting financial and technical assistance and grants from foreign countries and international organizations;

- In order to promote investment opportunities in the country and promote exports, it is planned to hold various events abroad.[2] The main purpose of these measures is to further enhance the development of Uzbekistan and serve the well-being of the people.

The country's economic openness and attractiveness for investment and business, the desire to solve all problems on the basis of unity, mutual respect and solidarity, the pursuit of balanced and mutually beneficial relations with leading and other countries, political trust and international law - This is how our foreign partners describe the foreign policy course pursued by the President of Uzbekistan Shavkat Mirziyoyev. Uzbekistan is going through a historic and decisive stage of development. The country is implementing an unprecedented program of socio-economic and socio-political reforms. This, in turn, will help Uzbekistan to become one of the 50 most economically developed countries in the world by 2035 . This goal can only be achieved through successful and consistent integration into the global economic and financial system. To develop mutually beneficial, effective and multifaceted cooperation for Uzbekistan with leading countries of the world such as Russia, USA and China, developed countries in the Asia-Pacific region, in particular, the Republic of Korea and Japan, European countries and the European Union, Arab-Muslim and Turkic-speaking countries important. The main task of economic diplomacy is to attract investment and technology, expand domestic exports, promote the brand of national companies in foreign markets, strengthen the competitiveness of the country's economy, develop tourism. Today, this direction has become an integral part of our work. In recent years, in accordance with the instructions of President Shavkat Mirziyoyev, the interaction of the Ministry of Foreign Affairs with the Ministry of Investment and Foreign Trade of the Republic of Uzbekistan has been strengthened in the implementation of a single foreign policy and foreign economic activity. Appropriate structures have been set up to coordinate the joint efforts of the two ministries. In order to diversify exports of goods and services, attract investment and advanced technologies to the country, increase the flow of tourists, new approaches are being introduced to the working methods and system of the Ministry and diplomatic missions of Uzbekistan abroad.[3] In particular, as a result of the attachment of the staff of the Ministry and our embassies abroad in each region, the acceleration of the flow of investments and the solution of the problems of exporting enterprises on the spot.

On the issue of economic diplomacy, the President sets great tasks for the Ministry of Foreign Affairs. First, to attract investment. Second, the growth of exports of Uzbek products. Third, the increase in the number of tourists visiting Uzbekistan.[4]

Thanks to the development of modern mechanisms of foreign economic activity, the effectiveness of attracting foreign investment 
CURRENT RESEARCH JOURNAL OF HISTORY 2(9): 32-35, September2021

DOI: https://doi.org/10.37547/history-crjh-02-09-09

ISSN 2767-472X

(C)2021 Master Journals

\section{Crossref dof 81 Google}

Accepted 25th September, 2021 \& Published 30 th September, 2021

and new technologies, expanding the flow of tourists to Uzbekistan, increasing exports of national products to world markets, forming international transport corridors and other infrastructure projects has increased.[5] These efforts will contribute to the development of the Uzbek economy, as well as the further acceleration of tourism, investment and transport infrastructure.

In 2020, with the direct assistance of the Ministry of Foreign Affairs, 900 export contracts worth \$800 million were signed, targeted assistance was provided to 250 large domestic exporters and new markets were developed by exporting 211 types of products to 42 countries. As part of the Investment Program of the Republic of Uzbekistan for 2020-2022, more than 5,000 foreign specialists have been attracted to the country, and about 3,000 foreign technologies have been imported. The Multilateral Trust Fund for Human Security for the Aral Sea Region has received \$ 26.1 million from foreign donors.[6] At the heart of these efforts is the development of Uzbekistan, as well as the well-being of the people. Also, due to the projects implemented by the Ministry of Foreign Affairs and the open and constructive implementation of relations with foreign countries, Uzbekistan is actively promoting economic diplomacy in foreign policy.

Paragraph 1 of the Decree of the President of the Republic of Uzbekistan dated April 5, 2018 No PF-5400 "On measures to radically improve the system of the Ministry of Foreign Affairs of the Republic of Uzbekistan and strengthen its responsibility in the implementation of foreign policy and foreign economic priorities" Practical measures have been taken to "revise and improve the activities of the Ministry of Foreign Affairs and foreign institutions of the Republic of Uzbekistan and the organizational and staffing framework, with an emphasis on the development of economic diplomacy".[7]
In accordance with the Presidential Decree, the Department of Economic Diplomacy has been established within the Ministry of Foreign Affairs, which is directly involved in promoting the country's foreign economic interests, attracting foreign investment and financial and technical assistance, and developing international cooperation in tourism.[8] Based on the experience of leading foreign countries, we can say that the establishment of a department in the Ministry of Foreign Affairs, which deals directly with economic diplomacy, will contribute to the economic development of the country and increase investment attractiveness. This experiment has been implemented in economically developed countries such as the United Kingdom, Germany, France, Canada and Japan, and has shown its effectiveness.

Strengthening ties with the international business community, accelerating cooperation with the International Monetary Fund, the World Bank, the European Bank for Reconstruction and Development, the Asian Development Bank, the Islamic Development Bank and other major international organizations have become important areas of economic diplomacy.[9] It is important to maintain a relationship.

In conclusion, the active implementation of "economic diplomacy" in the foreign policy of Uzbekistan, the establishment of a special department of economic diplomacy in the Ministry of Foreign Affairs will make an important contribution to the economic development of the country. In making these efforts, we must perform important tasks while adhering to the principle of "now or never". It is necessary to develop practical measures for the implementation of the above tasks, studying international experience. From this point of view, we need to know that the contribution of economic diplomacy to the development of Uzbekistan is invaluable and serves the well- 
CURRENT RESEARCH JOURNAL OF HISTORY 2(9): 32-35, September2021

DOI: https://doi.org/10.37547/history-crjh-02-09-09

ISSN 2767-472X

(C)2021 Master Journals

\section{Crossref do) 81 Google}

Accepted 25 $5^{\text {th }}$ September, 2021 \& Published $30^{\text {th }}$ September, 2021

being of the people.

\section{Suggestions and recommendations}

- Establishment of a think tank for the development of economic diplomacy in the form of NGOs (NGOs) in order to further develop the economy of Uzbekistan, increase the attractiveness of investments and tourism potential; (From the British experience)

- Establishment of economic diplomatic relations with leading TMCs (Transnational corporations); (From the French experience)

- Arranging internships for the staff of the Department of Economic Diplomacy in the world's leading TMCs; (including the study of the system of work and economic relations with foreign countries)

- Establishment of regional branches of the Department of Economic Diplomacy; (with the establishment of a system of direct work with enterprises)

\section{ReFERENCES}

1. Мавланов И.Р. Экономическая дипломатия: Учеб. пособие. - 2-е изд., Университет мировойэкономики и дипломатии. - Москва: 000 Издательство «Аспект Пресс», 2016.- С. 34

2. 2021 йилга мўлжалланган “Ёшларни қўллаб-қувватлаш ва ақоли саломатлигини мустахкамлаш йили" давлат дастури. https://lex.uz/docs/5260791

3. Ўзбекистон

Республикаси Президентининг "Ўзбекистон Республикаси Ташқи ишлар вазирлиги тизимини тубдан такомиллаштириш хамда ташқи сиёсий ва ташқи иқтисодий фаолиятнинг устувор йўналишларини амалга оширишда унинг масъулиятини кучайтириш чоратадбирлари тўғрисида"ги 2018 йил 5 апрелдаги ПФ-5400-сон Фармони. https://lex.uz/docs/-3611072

4. Ташқи ишлар вазири Комилов А.Х. Замонавий дунёда Ўзбекистон ташқи сиёсатининг кун тартиби. http://www.isrs.uz/oz/ozbekistonyangil iklari/zamonaviy-dunyoda-ozbekistontashqi-siyosatining-kun-tartibi (2020 йил 27 август)

5. Ташқи ишлар вазири ўринбосари Неъматов И.Т. “Марказий Осиёдаги келишмовчиликнинг асосий сабаби муросанинг йўқлиги эди". https://www.gazeta.uz/oz/2020/07/14/n ematov-markaziy-osiyo-integraciya/ (2020 йил 14 июл)

6. Ташқи ишлар вазири Комилов А.Х. Очиқлик, конструктивлик ва прагматик ёндашув. Ўзбекистон Президент Шавкат Мирзиёев бошчилигида ташқи сиёсатда қандай муваффақиятларга эришмоқда. https://mfa.uz/uz/press/news/2019/ochi qlik-konstruktivlik-va-pragmatikyondashuv-ozbekiston-prezident-shavkatmirziyoyev-boshchiligida-tashqisiyosatda-qanday-muvaffaqiyatlargaerishmoqda---21306 (2019 йил 30 декабр)

7. Ўзбекистон Республикаси Ташқи ишлар вазирлигининг 2020 йилдаги фаолияти хақида хисобот. https://mfa.uz/uz/press/news/2021/ozb ekiston-respublikasi-tashqi-ishlarvazirligining-2020-yildagi-faoliyati-haqidahisobot---29088 (2021 йил 09-январ) 